УДК 312.6:351.777.61(1-22)

Delegan-Kokajko S.V., Slabkiy G.O.

\title{
The impact of landfills on incidence and prevalence rate of diseases across rural population
}

\author{
SU "Uzhhorod national university", Uzhhorod, Ukraine \\ svetlanadel1@ukr.net,g.slabkiy@ukr.net
}

\author{
Делеган-Кокайко С.В., Слабкий Г.О. \\ ВПлив сміттезвалищ на захворюваність \\ та рівень поширеності захворювань \\ серед сільського населення \\ ДВНЗ «Ужгородський національний університет», \\ м. Ужгород, Україна
}

\author{
Делеган-Кокайко С.В., Слабкий Г.А. \\ Влияние свалок на заболеваемость \\ и уровень распространенности заболеваний \\ среди сельского населения \\ ГВУЗ «Ужгородский национальный университет», \\ г. Ужгород, Украина
}

\section{Introduction}

Handling the problem of solid household waste accumulated in landfills has become a topical environmental issue for Ukraine [1,2]. Both domestic wastes landfills and refuse dumps contaminating the surrounding areas, air, soils, reservoirs and others have a disastrous effect on the environment [3]. V.M. Boronos notes that during the storage of waste, new environmentally hazardous substances that pose a threat to the environment and human health are created [4]. Other researchers also point to the deterioration of the health of people living near landfills [5,6].

O. Moroz with co-authors indicates that microorganisms that are found in solid household waste are causative agents of hepatitis, tuberculosis, dysentery, ascariasis, allergic, skin and other diseases [7].

The studies held by foreign researchers indicate the impact of landfills on the increasing cancer incidence and birth effects in children [8].

The study of the impact of solid waste landfills and unauthorized landfills on the health condition of the population is a high priority task due to the fact that on the territory of Transcarpathia there are solid waste landfills and unauthorized dumps of different levels of loading and the type of waste they contain [9]. Such objects may have a different effect on the incidence and prevalence of illnesses in the population. While the state of solid domestic waste landfills and authorized landfills are partly controlled by the relevant regulatory authorities, unauthorized dumpings are out of any control and therefore are extremely hazardous.

The purpose of the work - to explore the impact of landfills on the incidence and the prevalence of diseases across rural populations.

\section{Materials and methods}

The study was carried out in the rural Mizhhirsky district of the Transcarpathian region, on the territory of which there is a certified waste landfill of the village Tishne and 64 unauthorized landfills. A visual inspection of the certified landfill of the village Tishne was conducted and the chemical composition of its soils was explored. In order to determine the impact of landfills on the health of the population of the district using statistical data, a comparison between the indicators of the incidence and the prevalence of disease across the rural populations of the Mizhhirsky region and the Transcarpathian region in the main categories of diseases for the period 2015 2017 was made.

\section{Results and their discussion}

During the study of the state of the domestic wastes landfill of Tishna village in the Mizhhirsky district, it was discovered that the landfill was operated in violation of the requirements of nature protection legislation, norms and standards of environmental safety. During the inspection of the territory, the following violations were found:

1. There is no fence or trench of $2 \mathrm{~m}$ in depth or a circumvallation of $2 \mathrm{~m}$ high all around the landfill site. For the purpose of obtaining of soil samples for intermediate and final isolation of landfill wastes solidification, neither trenching of $3-6 \mathrm{~m}$ in depth and of 6-12 $\mathrm{m}$ in width nor disposal pits have been arranged. Therefore, a direct littering of the surrounding areas is taking place.

2. Removed waste is not sprinkled over with a layer of soil of $0.2-0.5 \mathrm{~m}$, with the further soil-shifter or soil-packer stamping. The technology of disposal of waste is carried out with a deviation from the design solutions. Low density of stacking waste is defined.

3. There is insufficient record of quantity of delivered solid household waste in volume, the data of which 
must be entered into a special book, which should be stored at the landfill. The requirements of the Law of Ukraine "On Waste" are violated. Automobile tires, PET bottles are being delivered there which is a direct violation of the requirements of environmental safety.

4. There is no drainage. Therefore, there is a gradual, constant contamination of soils and underground aquifers with various pollutants, since the bottom and edge insulation screens of the landfill are only clayey. In the green zone of the landfill there are no control wells to detect the effect of waste storage on groundwater. There are no gas outlets for methane and other gases removal that are explosive or flammable. There is no artificial alkalizing (liming) of soils, which leads to acidification of soils and accelerates the processes of heavy metals migration.

5. In the economic zone neither area for washing containers nor washing stations for vehicles with cold running water supply have been arranged.

6. In the economic zone no necessary sanitary-built facilities for the operating personnel have been arranged.

7. There is no organized technological supervision over the operation on receiving of specific industrial waste at the landfill.
8. There is pollution of the atmosphere with "greenhouse gases" as well as with some other ones. There is no laboratory establishment to monitor the state of pollution of the atmosphere, of the water of open water bodies, of groundwater pollution in the working zone of the landfill and on the border of the sanitary protection zone.

9. The landfill is the center of reproduction and the existence of insects, rodents, the infectious agents of various contagious diseases, the spore forms of pathogenic microorganisms. This factor is extremely important as it directly affects human being environment.

10. Bad odor emission due to the processes of decomposition of organic waste (especially during the warm period of the year) can be also noticed.

Later a study of the chemical composition of the landfills in the village Tishne was conducted. In total six studies were pursued. The averaged results of the study of the soil chemical composition of the authorized waste disposal site in the village Tishne of the Mizhhirsky district are shown in Table 1.

\section{Table 1. Averaged results of the study of the chemical composition of the soils of the landfill in Tyshne village $(n=6 ; P=0.95)$}

\begin{tabular}{|c|c|c|c|c|c|c|c|c|c|c|}
\hline \multirow[b]{3}{*}{$\begin{array}{l}\text { The place of } \\
\text { sampling }\end{array}$} & \multicolumn{10}{|c|}{ Identifiable parameters } \\
\hline & \multicolumn{6}{|c|}{ Content of Heavy Metals (HM) (mg/kg) } & \multirow[b]{2}{*}{$\begin{array}{l}\mathrm{NO}_{2}^{-} \\
\mathrm{mg} / \mathrm{kg}\end{array}$} & \multirow[b]{2}{*}{$\begin{array}{l}\mathrm{NO}_{3}^{-} \\
\mathrm{mg} / \mathrm{kg}\end{array}$} & \multirow[b]{2}{*}{$\begin{array}{c}\mathrm{P}_{2} \mathrm{O}_{5} \\
\mathrm{mg} / \mathrm{kg}\end{array}$} & \multirow[b]{2}{*}{$\mathbf{p H}$} \\
\hline & 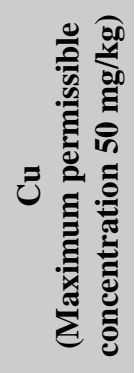 & 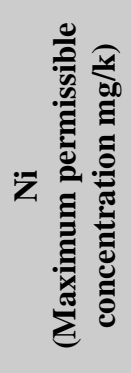 & 己 & 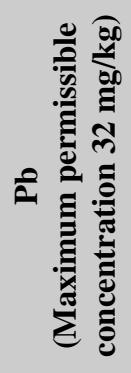 & 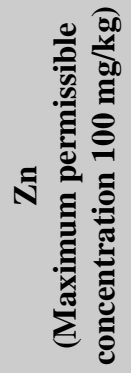 & 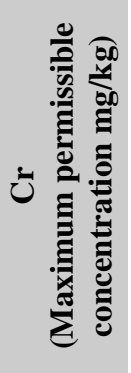 & & & & \\
\hline $\begin{array}{l}\text { Sample } 1 . \\
\text { Epicenter } \\
\text { of the landfill }\end{array}$ & $3.9 \pm 0.1$ & $<0.1$ & $<0.1$ & $2.3 \pm 0.1$ & $9.7 \pm 0.2$ & $<0.5$ & $2.4 \pm 0.1$ & $4819 \pm 256$ & $304 \pm 16$ & $5.1 \pm 0.3$ \\
\hline $\begin{array}{l}\text { Sample } 2.100 \mathrm{~m} \\
\text { from the landfill }\end{array}$ & $2.8 \pm 0.1$ & $<0.1$ & $<0.1$ & $1.4 \pm 0.1$ & $8.9 \pm 0.2$ & $<0.5$ & $1.8 \pm 0.1$ & $654 \pm 40$ & $212 \pm 14$ & $5.2 \pm 0.4$ \\
\hline $\begin{array}{l}\text { Sample } 3.200 \mathrm{~m} \\
\text { from the landfill }\end{array}$ & $2.5 \pm 0.1$ & $<0.1$ & $<0.1$ & $1.2 \pm 0.1$ & $5.8 \pm 0.1$ & $<0.5$ & $1.8 \pm 0.1$ & $642 \pm 42$ & $203 \pm 14$ & $5.9 \pm 0.4$ \\
\hline $\begin{array}{l}\text { Sample } 4.500 \mathrm{~m} \\
\text { from the landfill }\end{array}$ & $2.2 \pm 0.1$ & $<0.1$ & $<0.1$ & $1.1 \pm 0.1$ & $3.4 \pm 0.1$ & $<0.5$ & $1.1 \pm 0.1$ & $441 \pm 26$ & $191 \pm 12$ & $6.8 \pm 0.4$ \\
\hline $\begin{array}{l}\text { Sample } 5 . \\
\text { Wood line area }\end{array}$ & $1.3 \pm 0.1$ & $<0.1$ & $<0.1$ & $1.0 \pm 0.1$ & $2.9 \pm 0.1$ & $<0.5$ & $1.5 \pm 0.1$ & $514 \pm 31$ & $206 \pm 12$ & $7.2 \pm 0.2$ \\
\hline
\end{tabular}

In samples of soils selected on the territory of the landfill, an increased number of nitrite and nitrate ions, which significantly exceeds the similar index of control soil samples, were found. This testifies the intensification of nitrification processes in landfills, which poses a danger due to the high ability of compounds of nitrates to migrate, including ground and surface waters. The content of moving phosphorus forms in the soils of the landfill is high which indicates a gradual degradation of these soils. Comparing the data of the actual acidity values for the test sites of samples No. 2, 3, 4, 5 and the landfill site Sample No. 1, it is evident that the soils of the landfill are acidic due to the absence of artificial alkalization. The content of heavy metals in the soils of landfills and in soils below does not exceed the maximum permissible concentrations (for arable lands). 
The next step of the research was to study and compare the indicators of the incidence of diseases across the rural populations of the Transcarpathian region and the Mizhhirsky district by the main categories of diseases in the dynamics in 2015-2017 years. The incidence rate was calculated per 100 thousand population of the respective territory.

The results obtained during the study are shown in Table 2 .

Table 2. A prevalence rate of the population of the Transcarpathian region and Mizhhirsky district by main categories of diseases (per 100 thousands of population) in the years 2014-2017

\begin{tabular}{|c|c|c|c|c|c|c|c|c|}
\hline \multirow{2}{*}{ Category of disease } & \multicolumn{2}{|c|}{2015} & \multicolumn{2}{|c|}{2016} & \multicolumn{2}{|c|}{2017} & \multicolumn{2}{|c|}{$\begin{array}{l}\text { The ratio between } \\
\text { inndicators of the } \\
\text { Mizhirsky district and } \\
\text { the Transcarpathian } \\
\text { region }\end{array}$} \\
\hline & $\begin{array}{c}\text { Mizhhirsky } \\
\text { district }\end{array}$ & $\begin{array}{l}\text { Trans- } \\
\text { carpathian } \\
\text { region }\end{array}$ & $\begin{array}{c}\text { Mizhhirsky } \\
\text { district }\end{array}$ & $\begin{array}{l}\text { Trans- } \\
\text { carpathian } \\
\text { region }\end{array}$ & $\begin{array}{c}\text { Mizhhirsky } \\
\text { district }\end{array}$ & $\begin{array}{l}\text { Trans- } \\
\text { carpathian } \\
\text { region }\end{array}$ & $\begin{array}{c}\text { Per } 100 \\
\text { thousand } \\
\text { of } \\
\text { population }\end{array}$ & $\%$ \\
\hline $\begin{array}{l}\text { All kind of diseases, } \\
\text { including: }\end{array}$ & 53051.5 & 60515.1 & 57665.1 & 61084.6 & 56420.7 & 58729.9 & -2309.2 & -4.0 \\
\hline $\begin{array}{l}\text { Some infectious and } \\
\text { parasitic diseases }\end{array}$ & 1564.9 & 1566.4 & 1643.9 & 1576.5 & 1723.3 & 1429.4 & +293.9 & +60.6 \\
\hline Neoplasms & 394.3 & 649.1 & 334.6 & 665.5 & 288.6 & 668.7 & -380.1 & -56.8 \\
\hline $\begin{array}{l}\text { Blood diseases and } \\
\text { hematopoietic organs } \\
\text { and certain disorders } \\
\text { with the involvement of } \\
\text { the immune mechanism }\end{array}$ & 909.7 & 719.0 & 867.9 & 736.2 & 813.6 & 709.3 & +104.3 & +114.7 \\
\hline $\begin{array}{l}\text { Diseases of the } \\
\text { endocrine system, } \\
\text { nutrition and metabolic } \\
\text { disorders }\end{array}$ & 1815.3 & 1682.5 & 2444.9 & 1622.9 & 2323.6 & 1530.6 & +793.0 & +51.8 \\
\hline $\begin{array}{l}\text { Mental and behavioral } \\
\text { disorders }\end{array}$ & 26.5 & 17.6 & 19.6 & 27.96 & 16.4 & 15.5 & +0.9 & +5.8 \\
\hline Nervous system diseases & 2330.6 & 1505.4 & 2666.6 & 1472.0 & 2850.6 & 1537.3 & +1313.3 & +85.4 \\
\hline $\begin{array}{l}\text { Eye and its adnexa } \\
\text { apparatus diseases }\end{array}$ & 2336.7 & 3458.9 & 2248.3 & 3520.0 & 2388.4 & 3449.0 & -1060.6 & -30.8 \\
\hline $\begin{array}{l}\text { Ear and an apoptotic } \\
\text { appendix diseases }\end{array}$ & 1258.2 & 1890.5 & 1462.3 & 1873.6 & 1401.3 & 1855.7 & -454.4 & -24.5 \\
\hline $\begin{array}{l}\text { Blood circulation system } \\
\text { diseases }\end{array}$ & 4031.1 & 4782.9 & 4674.4 & 4855.3 & 5013.2 & 4859.5 & +153.7 & +3.2 \\
\hline Respiratory diseases & 24228.5 & 27167.0 & 27044.4 & 27592.3 & 22917.7 & 25938.3 & -3020.6 & -11.4 \\
\hline $\begin{array}{l}\text { Digestive system } \\
\text { diseases }\end{array}$ & 3728.6 & 4229.4 & 3570.1 & 4202.7 & 4147.3 & 4140.5 & +6.8 & +0.2 \\
\hline $\begin{array}{l}\text { Skin and subcutaneous } \\
\text { tissue diseases }\end{array}$ & 2557.6 & 2878.9 & 2097.7 & 2938.8 & 2116.5 & 2817.4 & -700.9 & -24.9 \\
\hline $\begin{array}{l}\text { Musculoskeletal system } \\
\text { and connective tissue } \\
\text { diseases }\end{array}$ & 1120.5 & 2270.9 & 1177.5 & 2346.6 & 1880.2 & 2328.0 & -447.8 & -19.2 \\
\hline $\begin{array}{l}\text { Genitourinary system } \\
\text { diseases }\end{array}$ & 1519.0 & 2435.1 & 1556.0 & 2380.0 & 2405.2 & 2577.4 & -172.2 & -6.7 \\
\hline $\begin{array}{l}\text { Birth defects, } \\
\text { deformities and } \\
\text { chromosomal } \\
\text { abnormalities }\end{array}$ & 75.1 & 136.4 & 100.4 & 113.3 & 77.4 & 110.8 & -33.4 & -30.1 \\
\hline $\begin{array}{l}\text { Injuries, poisoning and } \\
\text { some other effects of } \\
\text { external factors }\end{array}$ & 4085.4 & 3770.8 & 4300.0 & 3881.4 & 4666.0 & 3591.3 & +1074.7 & +29.9 \\
\hline
\end{tabular}


The analysis of the data in Table 2 indicates that during the study period, the general disease prevalence rate of the population in the Transcarpathian region is higher than the general indicators of the morbidity of the population of the Mizhhirsky district, but while the disease prevalence rate of the population in the Transcarpathian region tends to decrease then the incidence rates of the population of the Mizhhirsky district have a tendency to increase.

According to the categories of diseases, the general prevalence rate of the population and its structure both in the Transcarpathian region and in the Mizhhirsky district have certain fluctuations but they are unreliable.

The analysis of differences in the disease prevalence rate of the population of Transcarpathian region and the Mizhhirsky district indicates the following.

The disease prevalence rate of the population of the Mizhhirsky district is significantly lower than those of the Transcarpathian region in general for the following categories of diseases: neoplasms $(56.8 \%)$, the eye and its adnexa diseases $(30.8 \%)$, birth defects, deformations and chromosomal abnormalities $(30.1 \%)$, skin and subcutaneous tissue diseases $(24.9 \%)$

The disease prevalence rate of the population of the Mizhhirsky district is significantly higher than across the population of the Transcarpathian region by the following categories of diseases: nervous system (85.4\%), some infectious and parasitic diseases (60.6\%), endocrine system, nutritional and metabolic disorders (51.8\%), injuries, poisoning and some other effects of external factors (29.9\%), blood and hematopoietic organs diseases and certain disorders involving immune mechanism (14.7\%).

Further the disease prevalence rate across the population of the Transcarpathian region and the Mizhhirsky district in main categories of diseases in the dynamics of 2015-2017 years were researched and compared. The disease prevalence rate across the population was estimated on the basis of the research of 100 thousand population of the respective territory. The results obtained during the study are shown in Table 3.

Table 3. The disease prevalence rate across the population of Ukraine and of the Transcarpathian region by major categories of diseases (per 100 thousands of population) in the years 2015-2017

\begin{tabular}{|c|c|c|c|c|c|c|c|c|}
\hline \multirow{2}{*}{ Category of disease } & \multicolumn{2}{|c|}{2015} & \multicolumn{2}{|c|}{2016} & \multicolumn{2}{|c|}{2017} & \multicolumn{2}{|c|}{$\begin{array}{c}\text { The ratio between } \\
\text { inndicators of the } \\
\text { Mizhirsky district and } \\
\text { the Transcarpathian } \\
\text { region }\end{array}$} \\
\hline & $\begin{array}{l}\text { Mizhhirsky } \\
\text { district }\end{array}$ & $\begin{array}{l}\text { Trans- } \\
\text { carpathian } \\
\text { region }\end{array}$ & $\begin{array}{l}\text { Mizhhirsky } \\
\text { district }\end{array}$ & $\begin{array}{l}\text { Trans- } \\
\text { carpathian } \\
\text { region }\end{array}$ & $\begin{array}{l}\text { Mizhhirsky } \\
\text { district }\end{array}$ & $\begin{array}{l}\text { Trans- } \\
\text { carpathian } \\
\text { region }\end{array}$ & $\begin{array}{c}\text { Per } 100 \\
\text { thousand } \\
\text { of } \\
\text { population }\end{array}$ & $\%$ \\
\hline $\begin{array}{l}\text { All kind of diseases, } \\
\text { including: }\end{array}$ & 131335.2 & 158506.1 & 134772.2 & 157577.1 & 137380.3 & 154351.6 & -16971.3 & -11.0 \\
\hline $\begin{array}{l}\text { Some infectious and } \\
\text { parasitic diseases }\end{array}$ & 2572.1 & 2530.0 & 2595.6 & 2435.6 & 2614.3 & 2321.2 & +293.1 & +12.6 \\
\hline Neoplasms & 2186.7 & 2937.0 & 1934.6 & 3027.7 & 1825.8 & 2971.0 & -1145.2 & -38.5 \\
\hline $\begin{array}{l}\text { Blood diseases and } \\
\text { hematopoietic organs } \\
\text { and certain disorders } \\
\text { with the involvement of } \\
\text { the immune mechanism }\end{array}$ & 2391.1 & 2054.0 & 2683.3 & 2057.6 & 2618.5 & 2025.0 & +593.5 & +29.3 \\
\hline $\begin{array}{l}\text { Diseases of the } \\
\text { endocrine system, } \\
\text { nutrition and metabolic } \\
\text { disorders }\end{array}$ & 7359.1 & 11736.7 & 7968.4 & 11864.8 & 8792.4 & 11859.1 & -3066.7 & -25.9 \\
\hline $\begin{array}{l}\text { Mental and behavioral } \\
\text { disorders }\end{array}$ & 260.5 & 250.5 & 247.9 & 238.9 & 234.2 & 236.0 & -1.8 & -0.8 \\
\hline Nervous system diseases & 5823.4 & 3789.8 & 5519.3 & 3762.3 & 6424.9 & 3810.7 & +2614.2 & +68.2 \\
\hline $\begin{array}{l}\text { Eye and its adnexa } \\
\text { apparatus diseases }\end{array}$ & 4575.7 & 6508.3 & 4676.5 & 6561.5 & 5082.2 & 6485.2 & -1403 & -21.6 \\
\hline $\begin{array}{l}\text { Ear and an apoptotic } \\
\text { appendix diseases }\end{array}$ & 2003.3 & 2476.5 & 2106.1 & 2418.8 & 2139.5 & 2423.0 & -283.5 & -11.7 \\
\hline $\begin{array}{l}\text { Blood circulation system } \\
\text { diseases }\end{array}$ & 40837.1 & 51381.9 & 41454.4 & 51013.2 & 42738.5 & 50714.3 & -7975.8 & -15.7 \\
\hline Respiratory diseases & 29158.9 & 32496.0 & 31727.8 & 32853.8 & 27653.0 & 31158.2 & -3505.2 & -11.3 \\
\hline
\end{tabular}




\begin{tabular}{|c|c|c|c|c|c|c|c|c|}
\hline $\begin{array}{l}\text { Digestive system } \\
\text { diseases }\end{array}$ & 10838.4 & 16714.5 & 10570.1 & 16002.6 & 11513.4 & 15557.7 & -4044.3 & -26.0 \\
\hline $\begin{array}{l}\text { Skin and subcutaneous } \\
\text { tissue diseases }\end{array}$ & 2610.2 & 3700.3 & 2357.1 & 3712.8 & 2601.7 & 3630.5 & -1028.8 & -28.3 \\
\hline $\begin{array}{l}\text { Musculoskeletal system } \\
\text { and connective tissue } \\
\text { diseases }\end{array}$ & 4321.2 & 5981.4 & 4519.6 & 5848.5 & 5398.0 & 5815.6 & -417.6 & -7.2 \\
\hline $\begin{array}{l}\text { Genitourinary system } \\
\text { diseases }\end{array}$ & 5589.8 & 5768.5 & 5759.8 & 5617.6 & 6715.6 & 5745.6 & +970 & +16.9 \\
\hline $\begin{array}{l}\text { Birth defects, } \\
\text { deformities and } \\
\text { chromosomal } \\
\text { abnormalities }\end{array}$ & 358.9 & 872.3 & 391.1 & 873.3 & 353.5 & 841.5 & -488.0 & -58.0 \\
\hline $\begin{array}{l}\text { Injuries, poisoning and } \\
\text { some other effects of } \\
\text { external factors }\end{array}$ & 4085.4 & 4006.3 & 4300.0 & 4149.8 & 4666.0 & 3855.2 & +810.8 & +21.0 \\
\hline
\end{tabular}

The analysis of the data in Table. 3 indicates that over the period of the study, the general rate of the prevalence of diseases across the population of the Transcarpathian region was higher than the general rate of the prevalence of diseases across the population of the Mizhhirsky district. But while the prevalence rate of diseases across the population of the Transcarpathian region tends to decrease, then indicators of the disease prevalence across the population of the Mizhhirsky district has a tendency to increase.

By the categories of diseases, the general rate of the prevalence of diseases across the population and its structure, both in the Transcarpathian region and in the Mizhhirsky district, as well as the disease prevalence rate of the population, have certain fluctuations, but they are unreliable.

The analysis of the differences in the prevalence of diseases across the population of the Transcarpathian region and the Mizhhirsky district indicates the following.

The prevalence rate of diseases across the population of the Mizhhirsky district is reliably lower than for the population of the Transcarpathian region in the following categories of diseases: birth defects, deformations and chromosomal abnormalities $(58.0 \%)$, neoplasms $(38.5 \%)$, diseases of the skin and subcutaneous tissue (28.3\%), diseases of the digestive system $(26.0 \%)$, endocrine system, nutritional and metabolic disorders $(25.9 \%)$,the eye and its adnexa diseases (21.6\%), the diseases of the blood circulation system (15.7\%)

The rate of the prevalence of diseases across the population of the Mizhhirsky region is significantly higher than across the population of the Transcarpathian region for the following categories of diseases: nervous system (68.2\%), blood and hematopoietic organs diseases and certain disorders with the involvement of immune mechanism (29.3\%), poisoning and some other effects of external factors (21.0\%), the diseases of genitourinary system (16.9\%), some infectious and parasitic diseases (12.6\%).

\section{Conclusions}

As a part of the study, it was found that the presence of landfills negatively affects the disease prevalence rate across the rural population and the prevalence of disease rate in certain categories of illnesses. Thus, the presence of landfills contributes to an increase in the level of disease incidence in the following categories: nervous system, some infectious and parasitic diseases, endocrine system, nutritional and metabolic disorders, injuries, poisoning and some other effects of external factors, blood and hematopoietic organs diseases and individual disorders involving immune mechanism. Also, the presence of landfill sites negatively affects the prevalence of diseases in the following categories: nervous system, blood diseases and hematopoietic organs and certain disorders involving immune mechanism, injuries, poisoning and some other effects of external factors, the diseases of genitourinary system and some infectious and parasitic diseases.

\section{References}

1. Myhota I.V. Problemy utylizaciji ta zneshkodgennya tverdyh pobutovyh vidhodiv i vdoskonalennya sposobiv jih vyrishennya. Ecologiya i pryrodokorystuvannya. 2008; 11: 94-102.

2. Cherep O.M., Vinnichenko V.N. Problema tverdyh bytovyh othodov: kompleksnyj podhod. Ekolajn, Ecologia. 1996; 43.

3. Ecologija zhyttja [Electronnyj resurs]. - Rezhym dostupu: http://www.ecolive.com.ua.

4. Ohlyad rezultatyvnosti pravoohoronnoji dijalnosti: Ukrajina. Serija ohlyadiv pravoohoronnoji dijalnosti. №6. Publikaciji Organizaciji Objednanyh Natsij. New York, Zheneva. 2000; 132.

5. Natsionalna dopovid' pro stan navkolyshnjogo pryrodnoho seredovyshja v Ukrajini u 2006 rotsi. K.: Vyd-vo Rajevs'koho. 2007; 164.

6. Arkhipova G.I., Galushka Y.O. Vplyv zvalysch pobutovyh vidhodiv na zdorovja ljudej. Visnyk NAU. 2009 ; 3: $217-219$. 
7. Moroz O. Economichni aspekty vyrishennya ecolohichnyh problem utilizaciji tverdyh pobutovyh vidhodiv. Moroz O., Svetukh A., Svetukh O. Monogr. Vinnytsja. UNIVERSUM. 2003; p. 110.

8. Bondarja O.I. Upravlinnya vidhodamy: Vitchiznjanyj ta zakordonnyj dosvid: posibnyk. Za red. Bondarja O.I. Ajva Plus LTD; 2008: p. 196.

9. Khilchevskyj V.K., Zabokrytska M.R., Kravchynskyj R.L. Ecolohichna standartyzacija ta zapobigannja vplyvu vidhodiv na dovkillya: K.: «Kyjivskyj Universytet». 2016; p.192.

Дата надходження рукопису до редакції: 10.01.2020 p.

The purpose - to explore the impact of landfills on the incidence and the prevalence of diseases across rural populations.

Materials and methods. The study was carried out in the rural Mizhhirsky district of the Transcarpathian region, on the territory of which there is a certified waste landfill of the village Tishne and 64 unauthorized landfills. A visual inspection of the certified landfill of the village Tishne was conducted and the chemical composition of its soils was explored. In order to determine the impact of landfills on the health of the population of the district using statistical data, a comparison between the indicators of the incidence and the prevalence of disease across the rural populations of the Mizhhirsky region and the Transcarpathian region in the main categories of diseases for the period 2015-2017 was made.

Results and their discussion. In the course of the study it was found that the presence of negatively affects the disease prevalence rate across the rural population and the prevalence of disease rate in certain categories of illnesses. Thus, the presence of landfills contributes to an increase in the level of disease incidence in the following categories: nervous system, some infectious and parasitic diseases, endocrine system, nutritional and metabolic disorders, injuries, poisoning and some other effects of external factors, blood and hematopoietic organs diseases and individual disorders involving immune mechanism. Also, the presence of landfill sites negatively affects the prevalence of diseases in the following categories: nervous system, blood diseases and hematopoietic organs and certain disorders involving immune mechanism, injuries, poisoning and some other effects of external factors, the diseases of genitourinary system and some infectious and parasitic diseases.

Key words: landfill, rural population, incidence of diseases, prevalence of diseases, impact, indicators. населення.

Мета дослідження - вивчити вплив сміттєзвалищ захворюваність та поширеність хвороб серед сільського

Матеріали та методи. Дослідження було проведено у сільськогосподарському Міжгірському районі Закарпатської області, на території якого діє сертифіковане сміттєзвалище у селищі Тишне та 64 незареєстрованих сміттєзвалища. Було проведено візуальну інспекцію сертифікованого сміттєзвалища у селищі Тишне та вивчено хімічний склад грунту. 3 метою визначення впливу сміттєзвалищ на здоров'я населення району було застосовано статистичні показники, а також проведено порівняння між показниками захворюваності і поширеності хвороби серед сільського населення Міжгірського району та Закарпатської області в основних категоріях хвороб за період 2015-2017 років.

Результати та обговорення. В ході дослідження було виявлено наявність негативного впливу на швидкість поширення захворювання серед сільського населення і поширеність захворюваності в певних категоріях захворювань. Таким чином, наявність сміттєзвалищ сприяє підвищенню рівня захворюваності на хворобу в наступних категоріях: нервової системи, деяких інфекційних і паразитарних захворюваннях, ендокринної системи, харчових і метаболічних розладів, травм, отруєнь і деяких інших зовнішніх чинників, захворювань крові та кровотворних органів та індивідуальних розладів, пов'язаних 3 імунним механізмом. Також наявність сміттєзвалищ негативно впливає на поширеність захворювань в наступних категоріях: нервова система, захворювання крові і кровотворних органів і певні розлади, пов'язані з імунним механізмом, травмами, отруєнням і деякими іншими зовнішніми чинниками, захворювань сечостатевої системи та деяких інфекційних і паразитарних захворювань.

Ключові слова: сміттєзвалища, сільське населення, захворюваність, поширеність хвороб, вплив, показники.

Цель исследования - изучить влияние мусорных свалок на заболеваемость и распространенность заболеваний среди сельского населения.

Материалы и методы. Исследование было проведено в сельскохозяйственном Мижгирском районе Закарпатской области, на территории которого находится сертифицированная свалка у села Тишне и 64 незарегистрированных свалки. Была проведена визуальная инспекция сертифицированной свалки в селе Тишне и изучен химический состав почвы. С целью определения влияния свалок на здоровье населения района использованы статистические данные и проведено сравнение показателей заболеваемости и распространенности заболевания среди сельского населения Мижгирского района и Закарпатской области в основных категориях болезней за период 2015-2017 годов.

Результаты и обсуждение. В ходе исследования было выявлено присутствие негативного влияния на скорость распространения заболеваний среди сельского населения и распространенность заболеваемости в определенных категориях болезней. Таким образом, наличие свалок способствует повышению уровня заболеваемости в следующих категориях заболеваний: нервной системы, некоторых инфекционных и паразитарных заболеваний, эндокринной системы, пищевых и метаболических расстройств, травм, отравлений и некоторых других внешних факторов, 
заболеваний крови и кроветворных органов и индивидуальных расстройств, связанных с иммунным механизмом. Также наличие свалок негативно влияет на распространенность заболеваний в следующих категориях: нервная система, заболевания кровы и кроветворных органов и определенные расстройства, связанные с иммунным механизмом, травмами, отравлениями и некоторыми другими внешними факторами, заболеваний мочеполовой системы и некоторых инфекционных и паразитарных заболеваний.

Ключевые слова: свалки, сельское население, заболеваемость, распространенность болезней, влияние, показатели.

Конфлікт інтересів: відсутній.

Conflicts of interest: authors have no conflicts of interest to declare.

\section{Відомості про авторів}

Делеган-Кокайко Світлана Василівна - кандидат хімічних наук, доцент кафедри екології та навколишнього середовища ДВНЗ «Ужгородський національний університет»; м. Ужгород, пл. Народна, 3.

+380 (66) 800-53-91, svetlanadel1@ukr.net.

Слабкий Геннадій Олексійович - доктор медичних наук, професор, завідувач кафедри наук про здоров’я ДВНЗ «Ужгородський національний університет»; м. Ужгород, пл. Народна, 3.

+380 (50) 171-16-48, g.slabkiy@ukr.net. 